\title{
Characterization of Morococcus cerebrosus gen. nov., sp. nov. and Comparison with Neisseria mucosa
}

\author{
P. A. LONG, L. I. SLY, A. V. PHAM, AND G. H. G. DAVIS \\ Department of Microbiology, University of Queensland, St. Lucia, Queensland 4067, Australia
}

\begin{abstract}
We propose the name Morococcus cerebrosus gen. nov., sp. nov. for a gramnegative, oxidase-positive, aggregate-forming coccus that was isolated from a brain abscess. The type strain is UQM 858 (= ATCC $33486=$ NCTC 11393). A comparative study of this organism with Neisseria mucosa showed that the deoxyribonucleic acid base ratios of these two species were comparable but that there were sufficient differences in their physiological, cultural, serological, and morphological characteristics to warrant the proposal of this taxon as a new genus in the family Neisseriaceae.
\end{abstract}

In this paper we describe a new bacterium, designated strain UQM 858, which was isolated in 1971 at the Royal Brisbane Hospital, Australia, from pus obtained from a cerebellar abscess in a 54-year-old woman. This organism has been maintained by freeze-drying and has been examined sporadically by numerous microbiologists, but its identity has remained uncertain.

This isolate is a small, spherical organism which forms tightly bound mulberry-like aggregates of 10 to 20 cells that are difficult to disrupt; single cells, pairs, or tetrads are rarely observed. This morphology is similar to the conglomerate stage of Geodermatophilus. However, this organism is gram negative, oxidase positive, and nonmotile and physiologically is similar to some species of Neisseria. In this paper we compare it with one species which has been reported to comprise cocci held together in masses, Neisseria mucosa (12).

\section{MATERIALS AND METHODS}

Bacterial strains. Table 1 lists the strains used in this study.

General methods. Unless otherwise indicated, all tests were performed at $37^{\circ} \mathrm{C}$. Inocula were prepared by growing the bacteria on peptone yeast extract (peptone [Difco Laboratories, Detroit, Mich.], $10 \mathrm{~g}$; yeast extract [Difco], $5 \mathrm{~g}$; $\mathrm{NaCl}, 5 \mathrm{~g}$; distilled water, $1,000 \mathrm{ml} ; \mathrm{pH} 7.2)$ and harvesting them into phosphatebuffered saline (PBS) $\left(\mathrm{NaCl}, 8 \mathrm{~g} ; \mathrm{K}_{2} \mathrm{HPO}_{4}, 1.21 \mathrm{~g}\right.$; $\mathrm{KH}_{2} \mathrm{PO}_{4}, 0.34 \mathrm{~g}$; distilled water, $1,000 \mathrm{ml}$; $\mathrm{pH} 7.2$ ). Cells were concentrated by centrifugation at $1,500 \times g$ for $10 \mathrm{~min}$

Morphology. Samples for both scanning electron microscopy and transmission electron microscopy were grown in peptone yeast extract broth (PYEB) for $18 \mathrm{~h}$ on a model G10 Gyrotory shaker (New Brunswick Scientific Co., New Brunswick, N.J.) at $200 \mathrm{rpm}$. After centrifugation, the pellets were fixed without staining and were dehydrated in ethanol (16). Samples for scanning electron microscopy were examined with a Stereoscan Mk 2A electron microscope (Cambridge
Scientific Instruments, Cambridge, England). Samples for thin sectioning were embedded in Epon 812 resin (16), sectioned with a model OMU2 ultramicrotome (Reichert, Vienna,, and stained with $1.2 \%$ lead citrate for $10 \mathrm{~min}$ and with $4 \%$ uranyl acetate for $20 \mathrm{~min}$. Samples for negative staining were taken from 18-hold peptone yeast extract agar (PYEA) cultures and were stained with $1 \%$ phosphotungstic acid for $30 \mathrm{~s}$. A model EM300 transmission electron microscope (N. V. Philips, Eindhoven, The Netherlands) was used for transmission electron microscopy.

Samples for light microscopy were grown for $18 \mathrm{~h}$ on PYEA and then stained by the Gram method. Alternatively, cells were emulsified in Loeffler methylene blue on a slide, and this preparation was compressed firmly with a cover slip. Other samples were taken from 48-h-old cultures on peptone sucrose agar (3) and PYEA. Each of these samples was mixed with 1 drop of Burke iodine and held on a slide for $1 \mathrm{~min}$; while the mixture was still wet, a drop of $10 \%$ nigrosin was added, and the sample was drawn across the slide and air dried.

Growth characteristics. Growth was assessed on PYEA, peptone sucrose agar, chocolate agar, Sabouraud dextrose agar (Oxoid Ltd., London, England), Czapek Dox agar (Oxoid), MacConkey single-strength agar (Merck \& Co., Inc., Rahway, N.J.), salmonellashigella agar (Oxoid), and PYEA containing $40 \%$ bile, $0.01 \%$ potassium tellurite, or $10 \% \mathrm{NaCl}$ and in PYEB.

Growth requirements. The temperature limits for growth were determined by observing growth in 5$\mathrm{ml}$ PYEB cultures incubated at different temperatures in a variable-temperature incubator (Lindner and May, Brisbane, Australia) over a 5-day period. The $\mathrm{pH}$ limits for growth were assessed with 3-day-old PYEA cultures whose initial $\mathrm{pH}$ values ranged from 5 to 10 . Basic nutrient requirements were determined by using the following media: glucose ammonium sulfate mineral salts broth (14), PYEA supplemented with $1 \%$ glucose, PYEA, $0.5 \%$ peptone agar, $0.5 \%$ yeast extract agar, $0.5 \%$ vitamin-free Casamino Acids agar, and $0.5 \%$ vitamin-free Casamino Acids agar supplemented with $0.01 \%$ yeast extract. All media were adjusted to $\mathrm{pH} 7.2$ before they were sterilized at $121^{\circ} \mathrm{C}$ for $15 \mathrm{~min}$.

Utilization of organic substrates. Catabolism of 
TABLE 1. Strains used in this study ${ }^{a}$

\begin{tabular}{lll}
\hline $\begin{array}{c}\text { Laboratory } \\
\text { no. }\end{array}$ & \multicolumn{1}{c}{ Name } & \multicolumn{1}{c}{ Source } \\
\hline UQM 858 & Original isolate & $\begin{array}{l}\text { Harper (from a brain } \\
\text { abscess) }\end{array}$ \\
UQM 1903 & N. mucosa & ATCC 19696 \\
UQM 1803 & E. coli & NCTC 9001 \\
UQM 70 & E. coli & SHL \\
UQM 556 & S. aureus & NCTC 6571 \\
\hline
\end{tabular}

${ }^{a}$ UQM, Culture Collection, Department of Microbiology, University of Queensland, Queensland, Australia; Harper, J. Harper, Royal Brisbane Hospital, Brisbane, Australia; ATCC, American Type Culture Collection, Rockville, Md.; NCTC, National Collection of Type Cultures, Central Public Health Laboratory, London, England; SHL, State Health Laboratory, Brisbane, Australia.

carbohydrates and alcohols $(1 \%, \mathrm{wt} / \mathrm{vol})$ in a peptone water base ( $1 \%$ peptone, $0.5 \% \mathrm{NaCl}, 0.003 \%$ bromocresol purple) was assessed by acid production. Utilization of malonate and citrate (Christensen) was also determined (14).

Production of specific enzymes or end products. We performed tests for indole production from peptone water, $\mathrm{H}_{2} \mathrm{~S}$ production from peptone cystine sulfate medium, urease, phenylalanine deaminase, and lysine, arginine, ornithine, and glutamic acid decarboxylases, as well as the methyl red and Voges-Proskauer tests (14). We used the methods of Holding and Collee (4) to detect catalase, phosphatase, and lecithinase and the method of Kovacs to detect cytochrome oxidase (6). Deoxyribonuclease activity was assessed by using deoxyribonuclease agar (Oxoid).

Hydrolysis of macromolecules. We used the methods of Skerman (14) to detect hydrolyses of cellulose, starch, gelatin, and chitin (commercially prepared chitin). Esculin, tributyrin, and Tween 80 hydrolyses were determined by the methods of Sneath (15), Holding and Collee (4), and Sierra (13), respectively. Nutrient agar containing $20 \%$ skim milk was used to detect casein hydrolysis.

Miscellaneous reactions. The nitrate reduction test, the litmus milk test, and the Hugh-Leifson oxidation fermentation test were performed as described by Skerman (14). Hemolysis of horse erythrocytes was assessed with a blood agar base (type CM55; Oxoid).

Antibiotic susceptibility. Oxoid DST agar plates were inoculated by spreading onto each plate $0.1 \mathrm{ml}$ of a cell suspension which was prepared in PBS to give an absorbance at $660 \mathrm{~nm}$ of 0.5 unit, using a Spectronic 20 spectrophotometer (Bausch \& Lomb, Inc., Rochester, N.Y.). Antibiotic disks (Mast Laboratories Ltd., Liverpool, England) were used, and the results were recorded after $24 \mathrm{~h}$.

Determination of DNA base composition. Deoxyribonucleic acid (DNA) was prepared by the method of Marmur (9), with additional pronase treatments after the lysis and ribonuclease steps. Pronase (catalog no. 53702; Calbiochem, La Jolla, Calif.) was used at a concentration of $50 \mu \mathrm{g} / \mathrm{ml}$, and the reaction mixtures were incubated at $37^{\circ} \mathrm{C}$ for $30 \mathrm{~min}$ to degrade protein.

DNA base compositions were determined by the thermal denaturation method (10). A Gilford model 2400 spectrophotometer fitted with a Haake propylene glycol circulating temperature bath was used to determine the thermal denaturation midpoint in the hyperchromic shift during thermal denaturation at $260 \mathrm{~nm}$. DNA samples were dissolved in $0.1 \times$ standard saline citrate and denatured at a concentration of $40 \mu \mathrm{g} / \mathrm{ml}$. Guanine-plus-cytosine values (in moles percent) were calculated from the following formula: $\% \mathrm{GC}_{\mathrm{x}}=$ \%GC $\mathrm{GTD}_{\mathrm{ST}}+2.44\left(T_{m_{\mathrm{x}}}-T_{m_{\mathrm{STD}}}\right)$, which is a reorganized form of the formula of Mandel and Marmur (8). $\left(\mathrm{GC}_{\mathrm{X}}\right.$ is the moles percent guanine-plus-cytosine value of the test strain DNA; $\mathrm{GC}_{\mathrm{STD}}$ is the moles percent value of the internal standard DNA, and $T_{m_{\mathrm{x}}}$ and $T_{m_{\mathrm{STV}}}$ are the thermal denaturation midpoint temperatures of the test strain DNA and the internal standard DNA, respectively.) The DNA of Escherichia coli UQM 1803, which has a guanine-plus-cytosine content of $51.7 \mathrm{~mol} \%$ (17), was used as an internal standard.

Pathogenicity. We investigated the pathogenicity of strain UQM 858 with 4- to 5-week-old Quackenbush mice, but Australian quarantine regulations prevented inoculation with $N$. mucosa. Bacteria were harvested from 18-h-old PYEB cultures into sterile PBS to give suspensions containing approximately $10^{6}$ colonyforming units per $\mathrm{ml}$. Samples $(0.5 \mathrm{ml})$ were injected into batches of six mice intraperitoneally or subcutaneously. This was repeated with an inoculum of $10^{9}$ colony-forming units per $\mathrm{ml}$.

Preparation of antiserum against strain UQM 858. Cells from 18-h-old PYEB cultures were killed with $0.5 \%$ Formalin, harvested, and washed twice in sterile PBS. The final immunogen was adjusted so that a 1:20 dilution gave an absorbance at $660 \mathrm{~nm}$ of 0.5 unit, using a Spectronic 20 spectrophotometer (Bausch \& Lomb) and then was checked for sterility by culturing before it was frozen and stored at $-20^{\circ} \mathrm{C}$. Two outbred rabbits were each inoculated with four subcutaneous injections twice weekly for 4 weeks. Each rabbit received a total of $0.5 \mathrm{ml}$ on the first occasion, $1.0 \mathrm{ml}$ on the second, and $2.0 \mathrm{ml}$ on each subsequent occasion. The rabbits were bled 3 weeks after the final inoculation, and the serum was stored at $-20^{\circ} \mathrm{C}$. Control serum was obtained from an untreated rabbit. Absorbed serum samples were prepared by adding cells of strain UQM 858 or $N$. mucosa UQM 1903 at the immunogen concentration described above to serum in a ratio of $1: 9(\mathrm{vol} / \mathrm{vol})$ and incubating the preparation at $37^{\circ} \mathrm{C}$ for $2 \mathrm{~h}$. Absorbed sera were recovered by centrifugation and filtration through 0.45 $\mu \mathrm{m}$ membranes.

Indirect fluorescent-antibody test. Strain UQM 858 and $N$. mucosa UQM 1903 were tested against absorbed and unabsorbed UQM 858 antiserum. Staphylococcus aureus UQM 556 and $E$. coli UQM 70 were used as controls for nonspecific reactions. One drop of each bacterial suspension in PBS was air dried onto two areas of a microscope slide; one area was treated with UQM 858 antiserum diluted 1:9 in PBS, and the other was treated with PBS as a control. This was repeated by using absorbed sera and serum from the control rabbit. Slides were incubated at $37^{\circ} \mathrm{C}$ for 15 min, washed in running tap water for $2 \mathrm{~h}$ at a flow rate of 20 liters/h, blotted dry, and stained with fluorescein isothiocyanate-conjugated sheep immunoglobulin G anti-rabbit immunoglobulin (Commonwealth Serum 
Laboratories, Melbourne, Australia) diluted 1:49 with deionized water. These preparations were incubated as described above, rinsed thoroughly with distilled water, and mounted in a mixture of water and glycerol (1:9) for examination under oil immersion with an Olympus BH-RFL fluorescent microscope.

Gel immunodiffusion. PBS suspensions of strain UQM 858, N. mucosa UQM 1903, and E. coli UQM 70 at the concentrations described above were sonicated and allowed to diffuse overnight against control serum and UQM 858 antiserum (18).

Gel immunoelectrophoresis. Wells cut for electrophoresis were filled with samples of the sonic extracts described above. A current of $5 \mathrm{~mA}$ was applied in Veronal buffer for $90 \mathrm{~min}$ (18), and the separated antigens were allowed to diffuse overnight against control serum and strain UQM 858 antiserum. The precipitin lines from electrophoresis and from gel immunodiffusion were stained with Coomassie brilliant blue (13).

\section{RESULTS}

Growth and colony characteristics. Strain UQM 858 and N. mucosa UQM 1903 grew well on PYEA and chocolate agar but did not grow on Sabouraud dextrose agar, Czapek-Dox agar, salmonella-shigella agar, or PYEA containing $40 \%$ bile, $0.01 \%$ potassium tellurite, or $10 \% \mathrm{NaCl}$, or in glucose ammonium sulfate broth. The addition of glucose to PYEA enhanced growth, and although some growth occurred on agar media containing only peptone or yeast extract, better growth occurred when these two ingredients were combined, as in PYEA. Growth was poor on vitamin-free Casamino Acids medium, but it improved when yeast extract was added.

Strain UQM 858 grew only between 23 and $42^{\circ} \mathrm{C}$ and grew optimally between 33 and $40^{\circ} \mathrm{C}$. N. mucosa UQM 1903 grew between 23 and $40^{\circ} \mathrm{C}$, with optimum growth occurring between 33 and $38^{\circ} \mathrm{C}$. Strain UQM 858 grew within a $\mathrm{pH}$ range of 5.5 to 9.0 , whereas $N$. mucosa UQM 1903 grew between $\mathrm{pH} 6$ and 9 .

On PYEA after $24 \mathrm{~h}$, strain UQM 858 formed convex or umbonate, entire, buff-colored colonies which were $1 \mathrm{~mm}$ in diameter and had a frosted-glass appearance under reflected light. These colonies remained intact when they were moved and were extremely difficult to emulsify, but they were not adherent to the agar. After 48 $\mathrm{h}$, the colonies were between 1 and $2 \mathrm{~mm}$ in diameter. After 24 h, N. mucosa UQM 1903 formed convex, entire, shiny, buff-colored colonies which were $0.5 \mathrm{~mm}$ in diameter and mucilaginous but were not adherent to the agar or easily emulsified. After $48 \mathrm{~h}$, the colonies were $1 \mathrm{~mm}$ in diameter, more mucilaginous than before, and although isolated colonies could be moved, confluent growth adhered strongly to the agar.

On peptone sucrose agar after $48 \mathrm{~h}$, strain
UQM 858 produced nonadherent colonies which were $2 \mathrm{~mm}$ in diameter; $N$. mucosa UQM 1903 colonies were $1 \mathrm{~mm}$ in diameter, adherent, and very difficult to emulsify, and each was surrounded by a white halo in the agar. This halo stained black with Burke iodine. Colonies of both strains stained black with iodine on sucrose-containing agar, but in comparable media containing glucose, maltose, raffinose, or lactose in place of sucrose, there was no reaction with iodine. Samples of strain UQM 858 prepared by negative staining with nigrosin revealed a slime layer surrounding the clusters of cells; this layer was not observed when cells were grown without sucrose on PYEA (Fig. 1). This phenomenon could not be demonstrated with $N$. mucosa UQM 1903, although extracellular slime was detected in scanning electron micrographs of preparations from PYEB (Fig. 2A).

In static PYEB cultures, strain UQM 858 produced granular growth deposits, whereas $N$. $\mathrm{mu}$ cosa UQM 1903 formed stringy deposits which were difficult to disperse. In shaken PYEB cultures, strain UQM 858 exhibited granular growth, in contrast to the homogeneous turbid growth of $N$. mucosa UQM 1903. In wet mounts from PYEB cultures of strain UQM 858, some cell aggregates (see below) appeared as "ghosts," as if the cell contents had been released, leaving behind a pale shell-like structure. This may have resulted from autolysis, as often occurs with gonococci and meningococci.

Cell characteristics. Colonies of strain UQM 858 appeared to be constructed of masses of subunits which were 3 to $5 \mu \mathrm{m}$ in diameter. Each subunit usually contained 10 to 20 individual cells (diameter, approximately $0.8 \mu \mathrm{m}$ ) which were bound together firmly (Fig. 2B). Figure 2C shows that these cells were packed tightly and often were distorted; this figure also shows one of the ghost-type aggregates described above. The cell wall was comprised of three layers, which is typical of gram-negative bacteria, giving rise to the blebs and convoluted surface shown in Fig. 2D. The aggregate shown in Fig. 2D was
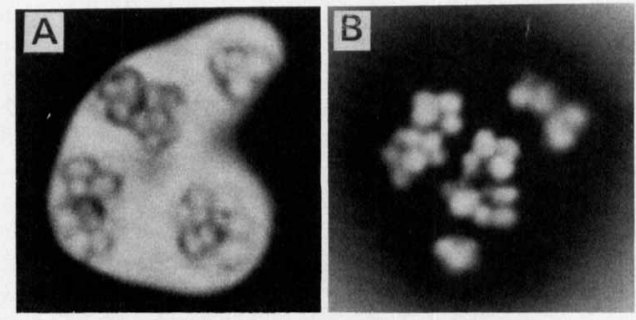

FIG. 1. Photomicrographs of strain UQM 858 neg atively stained with nigrosin. (A) Strain UQM 858 grown on peptone sucrose agar. (B) Strain UQM 858 grown on PYEA. $\times 2500$. 

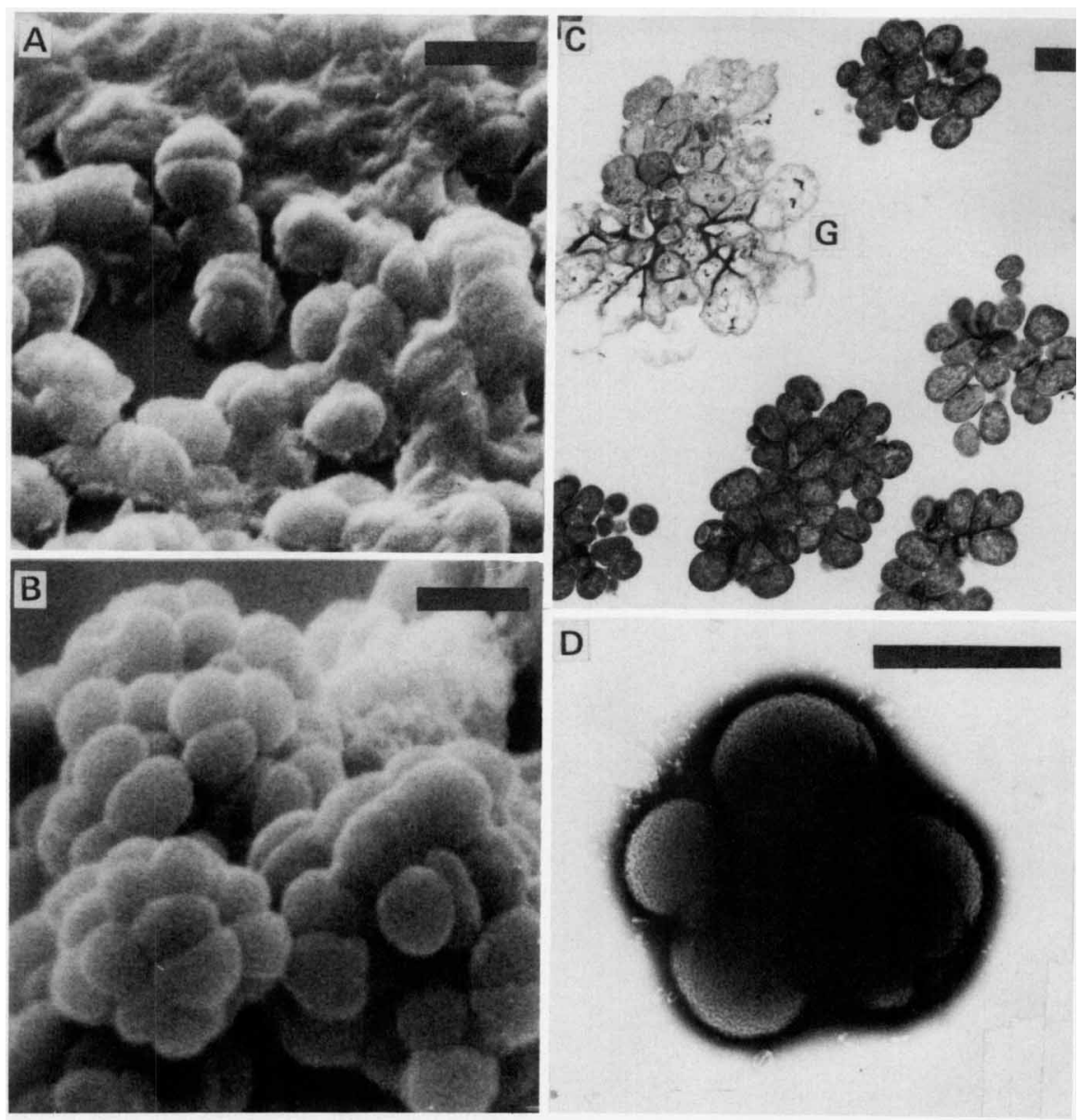

FIG. 2. Electron micrographs of strain UQM 858 and N. mucosa UQM 1903. (A) Scanning preparation of $N$. mucosa UQM 1903. (B) Scanning preparation of strain UQM 858. (C) Thin section of strain UQM 858 showing normal and ghost-type (G) aggregates. (D) Negatively stained preparation of strain UQM 858. Bar $=1 \mu \mathrm{m}$.

smaller than most, but it contained areas of the cell wall which were pinched in before further cell division. Electron microscopy failed to reveal the presence of flagella or pili or to indicate that the cells contained storage inclusions, such as poly- $\beta$-hydroxybutyrate.

Photomicrographs of strain UQM 858 were difficult to obtain due to the three-dimensional nature of the aggregates, particularly in wet mounts. However, the methylene blue preparation shown in Fig. 3A is typical of strain UQM 858 and is quite distinct from a preparation of N. mucosa UQM 1903 (Fig. 3B). Although the cells of $N$. mucosa UQM 1903 may be held together loosely by slime material (Fig. 2A), light microscopy has always revealed the cells as individuals, pairs, or tetrads.

Gram stains of strain UQM 858 appeared positive unless the ethanol decolorization was continued for 20 to $40 \mathrm{~s}$, and irregular staining was often observed. A typical Gram-stained preparation is shown in Fig. $3 \mathrm{C}$.

Physiology. Strain UQM 858 and $N$. mucosa UQM 1903 were identical in the following ways. They were aerobic but gave weak acid reactions in both tubes of the Hugh-Leifson test, were hemolytic on horse blood agar, produced $\mathrm{H}_{2} \mathrm{~S}$ from cystine, and were positive for deoxyribonuclease, catalase, cytochrome oxidase, and methyl red. Nitrate was reduced to nitrite and gas, although this reaction was sometimes variable. Acid was produced from glucose, fructose, maltose, and sucrose but not from arabinose, ribose, xylose, rhamnose, galactose, mannose, sorbose, salicin, cellobiose, lactose, melibiose, trehalose, melezitose, raffinose, dextrin, inulin, starch, ethanol, glycerol, erythritol, adonitol, arabinol, dulcitol, mannitol, sorbitol, or inositol. Citrate and malonate were not utilized. Starch, esculin, gelatin, casein, and Tween 80 were not 


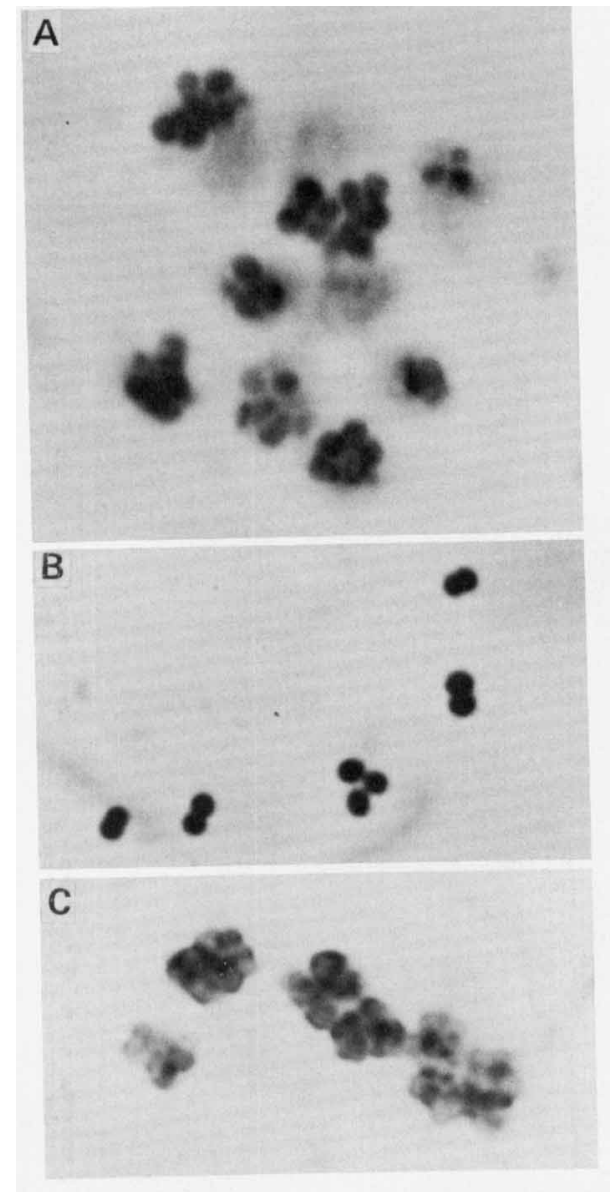

Fig. 3. Photomicrographs of strain UQM 858 and N. mucosa UQM 1903. (A) Strain UQM 858, methylene blue preparation. (B) N. mucosa UQM 1903, methylene blue preparation. (C) Strain UQM 858, Gram stain. $\times 3,000$.

hydrolyzed, and no growth occurred on chitin, cellulose, or tributyrin agar. Lecithinase, urease, phosphatase, and phenylalanine deaminase were not produced, serum was not liquefied, and indole was not produced from tryptophan.

Strains UQM 858 and N. mucosa UQM 1903 differed in the following ways. $N$. mucosa UQM 1903 strongly reduced litmus milk and grew on MacConkey agar but failed to produce acid reactions in Falkow decarboxylase tests. Strain UQM 858 reduced litmus milk weakly, failed to grow on MacConkey agar, gave a strong decarboxylase reaction for ornithine (but was negative for arginine, glutamic acid, and lysine decarboxylase), and yielded larger inhibition zones with the aminoglycoside antibiotics kanamycin, gentamicin, and streptomycin (Table 2).

DNA base ratios. From duplicate determinations, the guanine-plus-cytosine contents of the DNAs of strain UQM 858 and $N$. mucosa UQM 1903 were $52.3 \pm 0.6$ and $52.0 \pm 0.4 \mathrm{~mol} \%$, respectively.

Pathogenicity. Mice inoculated intraperitoneally with $10^{6}$ colony-forming units of strain UQM 858 per $\mathrm{ml}$ became ruffled within $24 \mathrm{~h}$ but completely recovered by $48 \mathrm{~h}$. Of those mice which received $10^{9}$ colony-forming units per ml, two died within $20 \mathrm{~h}$ and the remaining four died by $24 \mathrm{~h}$. Aggregates of bacteria resembling strain UQM 858 aggregates were observed microscopically in homogenized spleen preparations from dead animals.

Four of the six mice inoculated subcutaneously with either $10^{6}$ or $10^{9}$ colony-forming units per $\mathrm{ml}$ developed pyrogenic lesions of varying sizes at the sites of inoculation and showed lymph node involvement which persisted for more than 7 days. The larger lesions contained free pus, in which the bacteria were revealed by Gram staining and from which they could be recovered by culture.

Serology. In indirect fluorescent antibody tests, antiserum to strain UQM 858 showed no affinity for either of the controls (E. coli UQM 70 and S. aureus UQM 556) or for N. mucosa UQM 1903 but did react strongly with cells of strain UQM 858. Antiserum absorbed with strain UQM 858 lost this property, but the same serum absorbed with $N$. mucosa UQM 1903 remained reactive to strain UQM 858.

Gel immunodiffusion revealed three bands of precipitation between a strain UQM 858 sonic extract and a strain UQM 858 antiserum. These bands were not observed with sonic extracts of N. mucosa UQM 1903 or E. coli UQM 70. No bands appeared when control serum was used.

Gel immunoelectrophoresis was more sensi-

TABLE 2. Susceptibilities of strain UQM 858 and N. mucosa UQM 1903 to various antibiotics

\begin{tabular}{lcc}
\hline & \multicolumn{2}{c}{$\begin{array}{c}\text { Inhibition zone }(\mathrm{mm}) \\
\text { produced by: }\end{array}$} \\
\cline { 2 - 3 } \multicolumn{1}{c}{ Antibiotic disk } & Strain & N. mucosa \\
& UQM 858 & UQM 1903 \\
\hline Kanamycin $(30 \mu \mathrm{g})$ & 15 & 9.5 \\
Gentamicin $(10 \mu \mathrm{g})$ & 14 & 10 \\
Streptomycin $(10 \mu \mathrm{g})$ & 12 & 5 \\
Penicillin G $(10 \mathrm{U})$ & 9 & 9 \\
Cloxacillin $(5 \mu \mathrm{g})$ & $\mathrm{R}^{b}$ & $\mathrm{R}$ \\
Methicillin $(5 \mu \mathrm{g})$ & $\mathrm{R}$ & $\mathrm{R}$ \\
Ampicillin $(2 \mu \mathrm{g})$ & 8 & 8 \\
Erythromycin $(15 \mu \mathrm{g})$ & 9 & 10 \\
Nalidixic acid $(30 \mu \mathrm{g})$ & 13 & 12 \\
Chloramphenicol $(10 \mu \mathrm{g})$ & 11 & 12 \\
Tetracycline $(10 \mu \mathrm{g})$ & 12 & 11 \\
\hline
\end{tabular}

${ }^{a}$ Radius of the inhibition zone plus the disk minus the disk radius (mean of six replicates).

${ }^{b} \mathrm{R}$, Resistant (no inhibition zone). 
tive and revealed up to six precipitin arcs. Although the precise number of ares varied between replicate experiments, three major arcs were found consistently and were considered identical to the three bands described above. There was no reaction with sonic extracts of $N$. mucosa UQM 1903 or $E$. coli UQM 70, and there was no reaction when control serum was used.

The principal differences between strain UQM 858 and $N$. mucosa UQM 1903 are summarized in Table 3.

\section{DISCUSSION}

The characteristics of N. mucosa UQM 1903 (=ATCC 19696) have been described previously by Véron et al. (19). Berger and Miersch (2) also described a number of isolates confirmed as $N$. mucosa. As determined by us, the properties of the type strain of $N$. mucosa, strain ATCC 19696, were not identical to the properties described in previous reports $(2,19)$. Our findings differed from the previously reported findings in the following respects: starch hydrolysis was

TABLE 3. Differences between strain UQM 858 and N. mucosa UQM 1903

\begin{tabular}{|c|c|c|}
\hline Character & Strain UQM 858 & $\begin{array}{c}\text { N. mucosa UQM } \\
1903\end{array}$ \\
\hline Cell arrangement & $\begin{array}{l}\text { Irregular aggre- } \\
\text { gates of } 10 \text { to } \\
20 \text { cells }\end{array}$ & $\begin{array}{l}\text { Single, pairs, tet- } \\
\text { rads }\end{array}$ \\
\hline $\begin{array}{l}\text { Growth on } \\
\text { PYEA at } 48 \mathrm{~h}\end{array}$ & $\begin{array}{l}\text { Matt colonies } 1 \\
\text { to } 2 \mathrm{~mm} \text { in di- } \\
\text { ameter; growth } \\
\text { not adherent to } \\
\text { the agar }\end{array}$ & $\begin{array}{l}\text { Shiny, mucilagi- } \\
\text { nous colonies } 1 \\
\text { mm in diame- } \\
\text { ter; growth ad- } \\
\text { herent to the } \\
\text { agar }\end{array}$ \\
\hline $\begin{array}{l}\text { Growth on su- } \\
\text { crose peptone } \\
\text { agar at } 48 \mathrm{~h}\end{array}$ & $\begin{array}{l}\text { Colonies } 2 \mathrm{~mm} \text { in } \\
\text { diameter, re- } \\
\text { acting black } \\
\text { with iodine; } \\
\text { slime laver } \\
\text { around cell } \\
\text { clusters }\end{array}$ & $\begin{array}{l}\text { Colonies } 1 \mathrm{~mm} \text { in } \\
\text { diameter; black } \\
\text { reaction with } \\
\text { iodine extend- } \\
\text { ing into sur- } \\
\text { rounding agar; } \\
\text { slime layer ab- } \\
\text { sent }\end{array}$ \\
\hline Growth in PYEB & Granular & Stringy $^{a}$ \\
\hline $\begin{array}{l}\text { Growth in shaken } \\
\text { PYEB }\end{array}$ & Granular & Homogeneous \\
\hline $\begin{array}{l}\text { Growth on } \\
\text { MacConkey } \\
\text { agar }\end{array}$ & - & + \\
\hline $\begin{array}{l}\text { Acid production } \\
\text { in Falkow } \\
\text { amino acid } \\
\text { basal medium }\end{array}$ & + & - \\
\hline $\begin{array}{l}\text { Reduction of lit- } \\
\text { mus milk }\end{array}$ & Weak & Strong \\
\hline $\begin{array}{l}\text { Susceptibility to } \\
\text { aminoglycoside } \\
\text { antibiotics }\end{array}$ & Moderate & Low \\
\hline $\begin{array}{l}\text { Reaction with } \\
\text { antiserum } \\
\text { against strain } \\
\text { UQM } 858\end{array}$ & + & - \\
\hline
\end{tabular}

"Some strains of $N$. mucosa have been reported to exhibit granular growth (2). negative, $\mathrm{H}_{2} \mathrm{~S}$ production was positive (also reported by Berger and Miersch), the production of slime capsules could not be detected readily, and pronounced susceptibility to chloramphenicol and streptomycin could not be dernonstrated. Technical variations may account for some of these differences, and other differences, such as capsule loss, may have been due to changes induced by laboratory subculturing. Generally, however, our results were in accord with previously published data.

A comparison of strain UQM 858 with $N$. mucosa UQM 1903 revealed that these two strains are essentially identical in their growth requirements, in their DNA base ratios, and in most biochemical activities. However, they were not identical serologically, regardless of whether whole cells or sonicated cell preparations were used, and there were dissimilarities in other respects (Table 3). We feel that these results support the view that strain UQM 858 does not belong to the species $N$. mucosa.

The serological difference between strain UQM 858 and $N$. mucosa UQM 1903 does not necessarily mean that strain UQM 858 should be excluded from the genus Neisseria. Whereas Holten (5) found that antiserum to the malate dehydrogenase of Neisseria perflava reacted with extracts from many other species of Neisseria, Berger (1) reported serological differences (detected by immunodiffusion of whole-cell suspensions) between two subspecies of $N$. mucosa. Furthermore, using agglutination techniques, Véron et al. (20) found that $N$. mucosa was not related to Neisseria gonnorhoeae, Neisseria flavescens, Neisseria flava, or Neisseria perflava but that it was related to Neisseria sicca. Gel immunodiffusion studies with other bacteria have also shown that some species within a genus are antigenically related and others are not (7). However, because of the unusual cell configuration of strain UQM 858, we think that it would unnecessarily introduce confusion to include this strain in the genus Neisseria, the description of which provides for cocci occurring singly or often in pairs, with adjacent sides flattened (12). On the other hand, the family description of Neisseriaceae allows for spherical cells to be in masses with adjacent sides flattened, and thus this family could include strain UQM 858. Although other characteristics of strain UQM 858 are in accord with the family description, they do not comply with the specifications for the genera Branhamella, Moraxella, and Acinetobacter or with those for the genera Paracoccus and Lampropedia. For these reasons, we propose the name Morococcus cerebrosus sp. nov. as the name of the species which includes strain UQM 858. 
Morococcus gen. nov. (Mo.ro.coc'cus. L. neut. n. morum mulberry; Gr. $\mathrm{n}$. coccus a grain or berry; M.L. mas. n. Morococcus the mulberry coccus) is described as follows. Colorless, spherical organisms, less than $1 \mu \mathrm{m}$ in diameter, bound firmly together in tightly packed, mulberry-like aggregates of 10 to 20 cells, with adjacent sides often flattened. Gram negative. Nonmotile. Endospores not formed. Aerobic. Nitrate is reduced. Catalase and cytochrome oxidase are produced. $\mathrm{H}_{2} \mathrm{~S}$ is produced. Acid is produced from carbohydrates. Hemolytic. Complex growth factors not required. Growth occurs between 23 and $42^{\circ} \mathrm{C}$ and between pH 5.5 and 9.0. Ecological niche unknown, but originally isolated from a human brain abscess. The guanine-plus-cytosine content of the DNA is $52.3 \pm 0.6 \mathrm{~mol} \%$. The type species is $M$. cerebrosus sp. nov.

Morococcus cerebrosus sp. nov. (ce.re.bro'sus. L. adj. cerebrosus pertaining to the brain, the original source of isolation of this organism) is described as follows. Colorless, spherical organisms, less than $1 \mu \mathrm{m}$ in diameter, bound firmly together in tightly packed, mulberry-like aggregates of 10 to 20 cells, with adjacent sides often flattened. Gram negative. Nonmotile. Endospores not formed. Poly- $\beta$-hydroxybutyrate not produced. Capsules are produced in sucrose media.

Growth occurs on vitamin-free Casamino Acids, peptone, yeast extract, and chocolate agars. No growth occurs on Sabouraud dextrose agar, Czapek Dox agar, salmonella-shigella agar, MacConkey agar, or PYEA containing $40 \%$ bile, $0.01 \%$ potassium tellurite, or $10 \% \mathrm{NaCl}$ or in glucose ammonium sulfate broth. After $24 \mathrm{~h}$ colonies on PYEA are convex or umbonate, entire, matt, buff colored, $1 \mathrm{~mm}$ in diameter, and difficult to emulsify. Colonies on sucrose agar give a black reaction with iodine. Granular growth occurs in PYEB. Growth occurs between 23 and $42^{\circ} \mathrm{C}$ and between $\mathrm{pH} 5.5$ and 9.0.

Aerobic, but may give weak acid reactions in both tubes of the Hugh-Leifson test. Nitrate is reduced. Litmus milk is reduced. Hemolyzes horse erythrocytes. $\mathrm{H}_{2} \mathrm{~S}$ is produced from cystine. Deoxyribonuclease, ornithine decarboxylase, catalase, cytochrome oxidase, and methyl red positive. Acid is produced from glucose fructose, sucrose, and maltose but not from arabinose, ribose, xylose, rhamnose, galactose, mannose, sorbose, salicin, cellobiose, lactose, melibiose, trehalose, melezitose, raffinose, dextrin, inulin, starch, ethanol, glycerol, erythritol, adonitol, arabinol, dulcitol, mannitol, sorbitol, or inositol. Citrate and malonate are not oxidized. Does not hydrolyze starch, esculin, gelatin, casein, or Tween 80 . Lecithinase, phosphatase, phenylalanine deaminase, and urease are not produced. Arginine, glutamic acid, and lysine decarboxylases are not produced. Indole is not produced. Serum liquefaction is negative.

Susceptible to the following Mast Laboratories antibiotic disks: kanamycin $(30 \mu \mathrm{g})$, gentamicin $(10 \mu \mathrm{g})$, streptomycin $(10 \mu \mathrm{g})$, penicillin $\mathrm{G}$ $(10 \mathrm{U})$, ampicillin $(2 \mu \mathrm{g})$, erythromycin $(15 \mu \mathrm{g})$, nalidixic acid $(30 \mu \mathrm{g})$, chloramphenicol $(10 \mu \mathrm{g})$, and tetracycline $(10 \mu \mathrm{g})$. Resistant to cloxacillin (5- $\mu \mathrm{g}$ disk) and methicillin (5- $\mu \mathrm{g}$ disk).

Antigenically not related to $N$. mucosa UQM 1903. Pathogenic to mice.

The guanine-plus-cytosine content of the DNA is $52.3 \pm 0.6 \mathrm{~mol} \%$.

The type strain of $M$. cerebrosus is UQM 858 (UQM stands for the Department of Microbiology, University of Queensland, which is the Australian National Culture Collection). Cultures of the type strain have also been deposited with the American Type Culture Collection under the number ATCC 33486 and with the National Collection of Type Cultures as NCTC 11393.

\section{ACKNOWLEDGMENTS}

We thank T. McGregor and J. Westcott for assistance with the transmission electron microscopy, the University of Queensland Electron Microscope Centre for the scanning electron microscope work, and Gerda Wolff for help with the preparation of media. Also, we thank W. J. Halliday for advice on immunological aspects.

\section{REPRINT REQUESTS}

Reprints are not available.

\section{LITERATURE CITED}

1. Berger, U. 1978. Serologische Bestätigung der zwei Unteraten von Neisseria mucosa (Véron et al. 1959). Med. Mikrobiol. Immunol. 165:163-168.

2. Berger, U., and M. Miersch. 1970 . Zum normalen Vorkommen von Neisseria mucosa (Véron et al. 1959). Z. Med. Mikrobiol. Immunol. 155:186-191.

3. Hayward, A. C. 1960 . A method for characterizing Pseudomonas solanacearum. Nature (London) 186:405406.

4. Holding, A. J., and J. G. Collee. 1971. Routine biochemical tests, p. 1-33. In J. R. Norris and D. W. Ribbons (ed.), Methods in microbiology, vol. 6A. Academic Press, Inc., New York.

5. Holten, E. 1974. Immunological comparison of NADPdependent glutamate dehydrogenase and malate dehydrogenase in genus Neisseria. Acta Pathol. Microbiol. Scand. Sect. B 82:849-859.

6. Kovacs, N. 1956. Identification of Pseudomonas pyocyanea by the oxidase reaction. Nature (London) 178: 703.

7. Mahanta, I. C., and S. K. Addy. 1977. Serological specificity of Xanthomonas oryzae, incitant of bacterial blight of rice. Int. J. Syst. Bacteriol. 27:383-385.

8. Mandel, M., and J. Marmur. 1968. Use of ultraviolet absorbance-temperature profile for determining the guanine plus cytosine content of DNA. Methods Enzymol. 12B:195-206.

9. Marmur, J. 1961. A procedure for the isolation of deoxyribonucleic acid from microorganisms. J. Mol. Biol. 3: 208-218.

10. Marmur, J., and P. Doty. 1962. Determination of the 
base composition of deoxyribonucleic acid from its thermal denaturation temperature. J. Mol. Biol. 5:109-118.

11. Ouchterlony, O. 1953. Antigen-antibody reactions in gels. IV. Types of reactions in coordinated systems of diffusion. Acta Pathol. Microbiol. Scand. 32:231-240.

12. Reyn, A. 1974. Genus Neisseriaceae, p. 428-432. In R. E Buchanan and N. E. Gibbons (ed.), Bergey's manual of determinative bacteriology, 8th ed. The Williams \& Wilkins Co., Baltimore.

13. Sierra, G. 1957. A simple method for the detection of lipolytic activity of microorganisms and some observations on the influence of contact between cells and fatty substances. Antonie van Leeuwenhoek J. Microbiol. Serol. 23:15-22.

14. Skerman, V. B. D. 1967. A guide to the identification of the genera of bacteria, 2nd ed. The Williams \& Wilkins Co., Baltimore.

15. Sneath, P. H. A. 1956. Cultural and biochemical characteristics of the genus Chromobacterium. J. Gen. Micro- biol. 15:70-98.

16. Springer, E. L., and I. L. Roth. 1973. The ultrastructure of the capsules of Diplococcus pneumoniae and Klebsiella pneumoniae stained with ruthenium red. J. Gen. Microbiol. 74:21-31.

17. Starr, M. P., and M. Marmur. 1969. DNA base composition and taxonomy of phytopathogenic and other enterobacteria. J. Gen. Microbiol. 56:113-123.

18. Triscott, M. X., and G. H. G. Davis. 1979. A comparison of four methods for the serotyping of group B streptococci. Aust. J. Exp. Biol. Med. Sci. 57:521-527.

19. Véron, M., P. Thibault, and L. Second. 1959. Neisseria mucosa (Diplococcus mucosus Lingelsheim). I. Description bactériologique et étude du pouvoir pathogène. Ann. Inst. Pasteur Paris 97:497-510.

20. Véron, M., P. Thibault, and L. Second. 1961. Neisseria mucosa (Diplococcus mucosus Lingelsheim). II. Étude antigênique et classification. Ann. Inst. Pasteur Paris 100:166-179. 